\title{
Omgewingsetiek ten gunste van natuur én mens?
}

\author{
P.G.W. du Plessis \\ Departement Filosofie (Emeritus) \\ Randse Afrikaanse Universiteit \\ JOHANNESBURG
}

\begin{abstract}
Environmental ethics: a case for nature and man?

This article outlines three approaches to the relationship between man and the environment. An anthropocentric environmental ethics of dominion over and exploitation of the environment is contrasted to a nature-centred environmental ethics that reduces man's interests to that of nature. The alternative to an anthropocentric ethos, with its slogan of 'man/mind over nature/matter', is however, not to be found in an ecocentric ethos defending the opposite case of subordinating man and his cultural values to the holiness of environment. A third approach can be called the ethos of responsible stewardship attempting to reconcile the interests of human society with that of the environment.
\end{abstract}

Some implications of the theses 'man is a steward, not the owner of the earth' and 'man is an irreducible complement to, not an extension of the earth' and 'natural things also have a moral dimension' are investigated. This investigation results in a broadening of the boundaries of morality for the benefit to the environment.

To reconcile the interests of man and nature, the new ethics will i.a. have to extend man's responsibility beyond his fellowmen and his societal institutions to his fellow creatures. Without man, nature's inherent identity cannot be detected and nurtured but without nature, man cannot become a moral being.

\section{Inleiding}

Vanuit Christelik-filosofiese besinning is die afgelope kwarteeu opvallend min publikasies oor omgewingsetiek die wêreld ingestuur. "As recently as 
Omgexingsetiek ten gunste van natuur én mens?

1985, it would have been almost impossible to find a book on Christianity and ecology." (Breuilly \& Palmer, 1992:vii.) Daarby word die Westerse Christendom met sy leerstuk dat die mens die sentrum van die skepping is en die natuur moet verower deur 'n leefwyse van 'heers en beheers', verantwoordelik gehou vir besoedeling, uitbuiting en vernietiging van die natuuromgewing (Breuilly \& Palmer, 1992:39).

Daar was en word immers aanvaar dat etiek in hoof- en bysaak tog handel oor mense en dat die sedelike 'n eksklusief menslike aangeleentheid is (vgl. onder andere Stoker, 1967:236, 243-248). Op 'n keer het Albert Schweitzer die tekort aan 'n etiek wat rekening hou met ander lewende wesens nogal speels geformuleer toe hy gesê het dat daar gans te min diere in ons etiek rondloop! Intussen is daar tekens dat ons (postmodeme) Westerse kultuur besig is om sy gebrek aan 'n relevante en natuurvriendelike omgewingsetiek aan te pak. Ook die Christendom moet antwoord op beskuldigings dat dit ' $n$ groot aandeel het aan die uitbuiting en besoedeling van moeder natuur, juis vanweë sy eksklusief mensgerigte etiek.

In verband met die vraag wat met 'omgewingsetiek' bedoel word, kan 'n mens hoofsaaklik drie groepe skrywers of antwoorde oor milieuvraagstukke onderskei (vgl. onder andere hoofstuk 1 van Barbour, 1980 en Attfield, 1983). Antwoorde op die vraag varieer veral ooreenkomstig sieninge rondom die verhouding tussen mens en sy natuuromgewing. Daar is 'n etiek wat die verhouding sien in terme van die mens se baasskap oor en eksploitering van die natuuromgewing. Die artikel wil in dié verband aantoon dat so 'n antroposentriese benadering 'n anti-omgewingsetiek meebring wat die natuur as iets sonder morele status behandel. In sy aggressiwiteit teenoor die natuur bring dié benadering tog 'n spesifieke omgewingsetiek mee: 'n utilistiese omgewingsetiek.

Die tweede groep skrywers probeer 'n omgewingsetiek uitbou wat die natuur en milieu sentraal stel. Vanuit die mens se ekologiese verweefdheid met en afhanklikheid van die natuur word 'n vriendelike en harmoniese verhouding teenoor die natuuromgewing of milieu nagestreef: dit word 'n omgewingsetiek van verwantskap of simbiose (Achterberg, 1986:3) of van deelname genoem (Du Plessis, 1988:256). Met heelwat waardering vir die kritiek teen 'n antroposentriese omgewingsetiek wys die artikel ook daarop dat 'n ekosentriese omgewingsetiek van verwantskap die mens as sentrum inruil vir die natuur as sentrum. 'n Ekosentriese omgewingsetiek herberg (onbedoeld) ' $n$ teenstelling tussen mens en natuur en kan dus moeilik uitkom by ' $n$ vreedsame versoening tussen albei. 
P.G.W. du Plessis

Die artikel sluit in 'n groot mate aan by 'n derde groep skrywers wat al hoe meer konsentreer op 'n omgewingsetiek waarin die mens se verantwoordelikheid teenoor en sy respek vir die natuur beklemtoon word. Die (nie-utilistiese) inherente waarde van die natuur, die grense van mens, natuur en wetenskap, asook oorwegings wat verskille en die verbondenheid tussen mens en natuur in ag neem, word gebruik as groeipunte vir 'n (mens- en) natuurvriendelike etos om 'n omgewingsetiek van rentmeesterskap en herderskap te bevorder.

\section{2. 'n Omgewingsetiek ten gunste van die mens}

Streng gesproke het die eerste generasie skrywers nie 'n sistematiese omgewingsetiek bedryf nie; hulle siening oor die relasie mens-natuur het egter pertinente implikasies vir 'n etiek waarin die eiebelang van die mens oorheersend is en die natuur 'n dienstigheid tot die voordeel van die mens moet lewer. Die oorsprong van dié siening kan ook teruggevoer word na die begin van ons Westerse beskawing toe Griekse filosowe opgewonde geraak het oor die groot kloof tussen die mens en alle ander wesens. Later het die unieke waarde van die mens juis betekenis gekry in sy distansiëring van die natuurdinge rondom hom. So gaan dit onder andere in die Renaissance-tyd om die heerskappy van die mens en sy gees oor die niemenslike wêreld, insluitende die stoflike wêreld.

Die bekende slagspreuk van Francis Bacon 'kennis is mag' het ook gedurende die Aufklärung of Verligting as inspirasiebron gedien om die natuuromgewing te verower en te eksploiteer. Descartes se skeiding tussen subjek (mens) en objek (natuur) begin met die sekerheid en sentraalstelling van die 'ek' wat die res van die wêreld konstrueer; die ego cogito het verreikende gevolge vir die vestiging van menslike kennisheerskappy oor die wêreld. In die heerskappy oor die natuur demonstreer die mens sy vryheid. Ook Kant het ' $n$ toename in menslike vryheid bepleit deur die mens tot eie wetgewer te verklaar wat selfs wette aan die natuur voorskryf. Opmerklik is die utopistiese en selfversekerde toon van skrywers soos August Comte en Condorcet se toekomsverwagtings: deur die vordering in die wetenskappe word ons menswees bevorder (= onophoudelike groei van rasionele insigte) en word die natuur oorwin (= onophoudelike groei van ons mag).

... Condorcet, in his sketch of human progress, starts from a typical Renaissance setting which we also encounter with the classical economists, namely, man's struggle with nature. Condorcet views this as the cradle of all human progress; for in this battle, fought with the aid of reason, man gains victory after victory over nature ... (Goudzwaard, 1979:40). 
Frankryk het in 1848 selfs 'n Departement van Vooruitgang gehad! Die opening van die eerste wêreldtentoonstelling te Londen in 1851 impliseer ook 'n erkenning van die materiële vooruitgang van dié eeu en van die groeiende mag van die mens oor die fisiese wêreld. 'n Fundamentele geloof van die Verligting was dat positiewe wetenskappe en tegnologie die natuur en die menslike samelewing so kan beheers dat vooruitgang plaasvind. Selfs die Belle Époque het aan die begin van ons eeu 'n onvermurfbare vertroue in 'n kontinue en liniêre proses van vooruitgang van die nuwe epog uitgestraal.

Die Amerikaanse nyweraar Carnegie het teen die begin van die twintigste eeu ' $n$ veelseggende titel aan een van sy geskrifte gegee: Gospel of Wealth. Daarin beloof hy 'n nuwe lewe waarin armoede, onderdrukking en uitbuiting op aarde sal verdwyn as ons die wette van die industriële vooruitgang gehoorsaam. Vooruitgang is die wagwoord vir 'n beskawing wat kontinente en die hele wêreld en alle lewensektore wil verower.

\begin{abstract}
Vooruitgang - progress - was van de belangrijkste mythen van de Verlichting: waar het licht der rede de duisternis van geloof en bijgeloof verdrijft, waar radikaal wordt opgeruimd met een transcendente instantie die alle verstand te boven zou gaan, daar kan alleen maar sprake van verbetering, van voonuitgang zijn ... Na God en Openbaring werden nu Mens en Rede op een metafysisch voetstuk geplaatst en tot de kern van de vooruitgangsmythe uitgeroepen (Zijderveld, 1985:43).
\end{abstract}

Saam met ' $n$ toenemende sekularisasie van die Christelike geloof was/is daar ' $n$ afnemende verset teen die optimistiese verabsolutering van vooruitgang, wetenskap en tegniek.

Die bekende Industriële Rewolusie in Europa het gedurende die agtiende en negentiende eeu die mens se greep op die natuuromgewing ook tegnologies versterk. Die omgewing is gesien as 'n bron van onverwerkte materiaal waarvan winsgewende verbruikersware gemaak kan word. Deur planne vir groei soek hierdie benadering na 'n strategie om die omgewing te gebruik, te benut, te eksploiteer ter wille van die belange van die mens en sy samelewing. Dit gaan om die bevryding uit die heerskappy van die natuur, om die emansipasie van sosiaal-politieke en godsdienstige instellings. En hierby kon sosialiste sedert Marx hulle ook gemaklik aansluit. In voormalige kommunisties-sosialistiese Oos-Europese lande is die natuur in diens van die menslike samelewing omgewerk tot bruikbare produkte. Daar het natuur slegs 'n sosiale betekenis omdat dit 'n middel is om die gemeenskap se behoeftes te bevredig. 
P.G.W. du Plessis

Die magsmotief van die Verligting het in die wetenskap begin met die slagspreuk 'kennis is mag' en word in die hedendaagse tegniek voortgesit met die reklamespreuk 'tegniek ter wille van gemak en doeltreffendheid en welvaart en voorsprong'. Binne die vooruitgangsdenke is daar tog 'n verbinding tussen welvaart en moraliteit: menslike geluk hang grootliks af van ons nuttige besittings en welvaart. Die morele kwaliteit van menslike handelinge moet gemeet word deur die nuttige effek en genot wat dit meebring. Dié soort lewenshouding kan 'n mens as 'n utilistiese en hedonistiese moraal bestempel, want effek en genot en nuttigheid (vir die mens) is die enigste norm vir ons optrede teenoor die natuur wat ons wil oorwin.

In general there is agreement among Enlightenment thinkers with respect to their undaunted admiration of scientific, technical, and economic progress as the bearers of the greatest benefit and utility for all of society (Goudzwaard, 1979:50)

'n Bloudruk vir 'groei' laat die ratte vir produksie onophoudelik draai tot voordeel en gerief van die mens en tot eksploitasie van natuurlike hulpbronne met gepaardgaande besoedeling van skoon lug, water en grond. Op toepaslike wyse word dit 'n mensgesentreerde of antroposentriese omgewingsetiek genoem. (Kyk onder andere Barbour, 1978; Achterberg, 1986; Breuilly \& Palmer, 1992.)

Pragmatism, marxism, scientific humanism, French positivism, German mechanism: the whole swarm of smug antireligious dogmas emerging in the late eighteenth and nineteenth centuries and by now deeply entrenched in scientific, political, economic and educational institutions ..., if anything, they made nature an extention of and mere raw material for man (Gunter soos aangehaal deur Achterberg \& Zweers, 1986:97).

$\mathrm{Al}$ was die vraag 'wat is omgewingsetiek?' toe nie eens aan die orde gestel nie, kan ons dié benadering 'n omgewingsetiek van oorheersing en roofbou noem. Hier is eintlik geen sprake van 'n omgewingsetiek nie; hier is eerder sprake van 'n natuuronvriendelike mensetiek. So 'n mensgesentreerde moraal gee maklik aanleiding tot verbruik en misbruik van die omgewing met 'n verwaarlosing van die kultivering en versorging van die omgewing. Waar die omgewing op een of ander wyse versorg word, waar daar sprake is van natuurbehoud, is dit natuurbehoud ter wille van selfbehoud. Dit bly 'n saak van die mens se eiebelang (onder andere $s y$ ontspanningsbehoeftes, $s y$ behoefte aan mooi sonsondergange, $s y$ behoefte aan natuurlike hulpbronne). Natuurbewaring en natuurontwikkeling is in belang van mense; die welsyn van die mens en sy komende nageslagte word sentraal gestel. 
Omgewingsetiek ten gunste van natuur én mens?

Dit is 'n utilistiese beheersetiek wat die natuuromgewing deur mense vir mense gebruik.

So was dit 'n kwessie van mind over matter; die belange van die mens gaan vér voorop; die belange van die natuur en omgewing kom slegs indirek via die mens ter sprake.

\section{3. 'n Omgewingsetiek ten gunste van die omgewing}

Die afgelope drie dekades is die vooruitgangsgejuig gereeld versteur deur skrywers oor die milieukrisis. Gaandeweg word ons getuies daarvan dat vooruitgang ' $n$ messias met voete van klei is wat arbeiders uitbuit, industriële monopolieë laat toeneem, 'n groter gaping tussen armes en rykes laat ontstaan, grondstowwe, energievoorrade, plant- en diersoorte laat verdwyn - ook tot skade vir die mens om wie alles moet draai.

'n Nuwe milieugesentreerde etiek word ontwikkel langs twee lyne: eerstens is daar 'n reaksie wat talle negatiewe kante van die antroposentriese omgewingsetiek formuleer; voorbeelde hiervan is Roszak en in mindere mate ook Carson en die tweede rapport aan die Klub van Rome. In die jongste tyd sluit Machovec hierby aan as hy die antroposentriese benadering ook beskuldig van 'n egoïstiese paternalisme wat voortvloei uit 'n Männercivilisation (Machovec, 1988:217 e.v.) 'n Ontstellende ontdekking is gemaak: in sy ruimteskip-aarde is die mens besig om die aarde self as brandstof op te gebruik en om aardse lewe deur insek- en pesbestrydingsmiddels te vernietig (Carson, 1962). Dié scenario van Rachel Carson se Silent Spring (1962) is ook 'n kritiek op die mens se sug na kortstondige tegnologiese oplossings in sy strewe na welvaart, gerief en mag. Ons wetenskaplik-tegniese mag blyk tog ambivalent te wees:

Die met wetenskap en tegniek verkreë mag keer hom teen die mens. Die verselfstandigde wetenskap het ' $n$ toename van mag veroorsaak maar tegelyk ook vervreemding van diegene waaroor mag uitgeoefen word. Vir die landbou geld dat die natuur, plante en diere slegs geken word in soverre as wat hulle beheers en gemaak kan word. ... Mens en natuur word die slagoffer van die Verligting (Schuuman, 1988:15).

Tweedens word die simbiose tussen mens en natuur beklemtoon; die menslike optrede word afgestem op die lewensritme van die natuuropset soos in die geval van Aldo Leopold se sogenaamde land ethics.

... het gaat om een ecologie-probleem. Men moet deze aarde als één geheel benaderen, als een eindig systeem, waarin planten, dieren en mensen in een complexe interactie met zonnestraling, lucht, water en ander grondstoffen een 
P.G.W. du Plessis

samenhang vormen, en waarin storing van één van de componenten drastische gevolgen kan hebben voor het geheel (Vermeersch, 1993:17).

Milieu en omgewing en ekologie word meestal ook as wisselterme gebruik. Ekologie het ontwikkel as onderdeel van die biologie. Ernst Haeckel word as die vader daarvan beskou. Ekologie is dan die studie van die saamleef of saamwoon (oikos = woning) van diere en plante binne 'n natuurlike milieu/omgewing, 'n biotoop, 'n ekosisteem (Vermeersch, 1993:67). In aansluiting by ' $n$ vitalistiese en selfs ewolusionistiese benadering wat 'lewe' as die goue draad tussen mens en natuur sien, word die 'milieu' of omgewing by voorkeur as die saamwoon van lewende organismes gesien.

'n Aanvanklike reaksie teenoor die aggressiewe en manlike benadering tot die natuuromgewing was om alles wat tegnologies of beskawingsverwant is as boos te bestempel en die goeie te soek in alles wat natuur-lik is. Dit is 'n reaksie wat haar wortels onder andere het in 'n Neo-Romantiek wat sê dat die mens onderdeel van die natuuromgewing is en nie geskeie daarvan kan of mag leef nie. Die mens word eerder as 'n verlengstuk van die natuur verstaan en behandel: mens en natuur moet in vrede en harmonie leef. Omgewingsbewaring word dikwels gesoek in die behoud van 'n ongerepte en ongeskonde natuur. In poëtiese taal word ons deur die Indiaanse opperhoof Chief Seattle daaraan herinner dat die aarde nie aan die mens behoort nie, maar die mens behoort aan die aarde.

Alles hangt met alles samen. Wat er met de aarde gebeurt, gebeurt er met de kinderen van de aarde. De mens heeft het web van het leven niet zelf geweven; hij is slechts één draad ervan (Seattle, soos aangehaal deur Achterberg, 1986:52).

Die paternalistiese houding teenoor die natuur word vervang met 'n milieugesentreerde etiek wat aanleun by ' $n$ feministiese aanpak van sake. In haar boek The Death of Nature (1985) gee Carolyn Merchant 'n uiteensetting van hoe die patriargale metafoor die $16 \mathrm{de}$ - en 17de-eeuse rewolusie in die wetenskap gestempel het sodat die natuur - soos 'n vrou - onderwerp en tot ' $n$ onderdanige ingetoom moes word (Merchant, 1985:169). Tans en in die toekoms moet ons geslag en verdere generasies die gevaarlike gevolge van veral 'n Verligtingsdenke oor mens en natuur hanteer. Die resultaat van ongebreidelde wetenskaplik-tegniese beheersing van die organiese en anorganiese omgewing lei tot grootskaalse natuurontwrigting en milieuvervuiling en ten slotte tot die verwoesting van die natuur. Conquest van die natuur as titel en ondertoon van talle publikasies eindig in 'n destruction van die milieu as tema van 'n hedendaagse 
Omgewingsetiek ten gunste van natuur én mens?

klaaglied. Die negatiewe gevolge van bovermelde antroposentriese benadering tot die omgewing is op ironiese wyse deur die antropoloog Loren Eisely opgesom (soos aangehaal deur Wilkinson, 1981:15):

It is with the coming of man that a vast hole seems to open in nature, a vast black whirlpool spinning faster and faster, consuming flesh, stones, soil, minerals, sucking down the lightning, wrenching power from the atom, until the ancient sounds of nature are drowned in the cacophony of something which is no longer nature, something instead which is loose and knocking at the world's heart, something demonic and no longer planned - escaped, it may be - spewed out of nature, contending in a final giant's game against its master.

Die vooruitgang - tegnokraties geïnterpreteer en gelei deur 'n moderne rasionaliteitskonsep - stuit deurlopend op weerstand en op beperkings. Weerstand word geimpliseer in vrae soos die volgende: is die vooruitgang kontinu en tot wie se voordeel is dit? Die grense van vooruitgang word duidelik as gelet word op die beperktheid van grondstowwe, op die toenemende belasting van die omgewing deur die besoedeling van grond, water en lug; as gelet word op die uitwissing van spesies en die vernietiging van 'n natuurlike balans tussen habitat en voedsel (Vermeersch, 1993:46 e.v.). Moeder aarde se dravermoë van die eksponensiële bevolkingsontploffing het 'n besliste limiet. In hulle beroemde tweede rapport aan die Klub van Rome het Mesarovic en Pestel daarop gewys dat die ganse mensdom op 'n kruispad is en dat 'n etiese heroriëntering nodig is om die regte keuses te maak (Mesarovic \& Pestel, 1974). Ons besitlike uitbuitershouding en ons sug na bevrediging van eiebelang sal gou moet plek mak vir 'n vriendeliker houding teenoor die omgewing. Daar is 'n drang om die industriële kolos met sy depersonifikasie-effek af te skaal na 'n meer menslike grootte (Schumacher, 1978). Die Frankfurtse skool met Marcuse aan die spits het ' $n$ uitgebreide besef van wantroue in die weldade van ons konsumpsiemaatskappy versprei. Horkheimer en Adorno se diepsnydende kritiek toon aan dat die Verligting ' $n$ inherente dialektiek herberg wat meebring dat die 'verligting' van die rede in die wetenskaplik-tegniese beheersing vandag in sy teendeel verander het en daarmee verblinding en verduistering veroorsaak (Schuurman, 1985:32).

Die sogenaamde kontrakulturele bewegings van die sestigerjare wys voortdurend op die omgewingsbesoedelde effek van die tegniek en industrialisasie en op die depersonifikasie van die mens. Daarom stel Theodore Roszak en Charles Reich in hul boeke met die opspraakwekkende titels The Making of a Counter Culture (Roszak, 1968) en The Greening of 
America (Reich, 1972) dat die tegnologiese eksesse van ons eeu teengestaan moet word deur 'n gevoel van eenheid met die planeet aarde; in plaas van oorlog teen die natuur moet vrede met haar gesluit word. Die etos van die klein kommune word bepleit sodat die gevoel van vervreemding tussen mens en omgewing oorwin kan word (Roszak, 1968 en Reich, 1972). In plaas daarvan om 'n kloof tussen mens en natuur te skep, word die mens verkieslik in dieselfde kategorieë as haar omgewing verstaan.

Stel dus dat wij en de Aarde die ons het bestaan heeft geschonken inderdaad één enkel organisch netwerk zijn,... Stel tenslotte dat - zoals maar al te duidelijk is - de eerste behoefte van de planeet is om nu onze technologische en organisatorische uitspattingen te matigen opdat al haar in gevaar verkerende kinderen zouden mogen leven.

Wat doet de Aarde dan? Ze begint in ons iets aan te spreken - een levensideaal, een gevoel van identiteit - wat tot nu toe slechts binnen een zonderlinge en marginale minderheid werd gekoesterd ... En zo verschijnt er heel opeens, midden in het centrum van de stedelijk-industriële samenleving, een generatie die instinctief smacht naar een kwaliteit van leven die volledig onverenigbaar is met de reusachtigheid van onze economische en culturele structuren. En die schreeuw van persoonlijke pijn die die generatie uitbrengt is de eigen schreeuw om hulp van de planeet, haar protest tegen het groot-zijn van dingen dat één wordt met het onze. Dus beginnen we te zoeken naar alternatieven voor die persoon-en-planeet-verpletterende kolossaliteit (Roszak, 1980:83-84).

Die soort omgewingsetiek van simbiose baseer haar heftige kampanjes om wilde gebiede tot beskermde gebiede te proklameer op die sentrumposisie van die natuur. Dit wys op die destruktiewe invloed van die mens op sy omgewing en maak studies van ontbossing, van erosie, van oorbeweiding, van woestynvorming, van versouting as gevolg van besproeiingspraktyke, van pes- en onkruidbestrydingsmiddels en van nywerheidsuitbreiding én nywerheidsafval. Dié etiek soek na 'n herstel van die delikate balans en ketting tussen mens en haar omgewing; dit wys op verdwynende fossielbrandstowwe; dit wys die vinger na ons tegnologiese geriewe (onder andere dryfgas in spuitkannetjies en yskaste) as met vrees oor die gat in die osoonlaag gepraat word. Teenoor 'n strategie vir groei en eksploitering word 'n strategie vir oorlewing en 'vergroening' gesoek.

Aldo Leopold het in ons eeu ' $n$ eerste beredeneerde omlyning gegee van 'n alternatiewe omgewingsetiek wat vanuit 'n simbiose tussen mens en omgewing ontwikkel kan word (Leopold, 1968). Hy kan ook beskou word as ' $n$ voorbereider van die tweede generasie skrywers se idees. Sy omgewingsetiek is gebaseer op die idee dat mens en omgewing een aardse 
gemeenskap vorm, veral omdat die mens 'n onderdeel is van die omgewingsgemeenskap. Verwantskap - en nie vyandskap nie - tussen gees (mens) en stof (natuur) word gesoek. Die mens voel dat sy verbonde is en sy weet dat sy verwant is met alles in die natuur.

That land as a community is the basic concept of ecology, but that land is to be loved and respected is an extention of ethics. ... The land ethic simply enlarges the boundaries of the community to include soils, waters, plants, and animals, or collectively: the land (Leopold, 1968:223).

Met land bedoel hy alles op, bo of onder die aarde; dit is ' $n$ geheel; mens kan nie een deel vertroetel en ' $n$ ander deel verwoes nie. Die land is moreel relevant: kollektief en in haar lede; daarom het die mens 'n morele verpligtinge teenoor die land en teenoor haar lede. Die verhouding tussen mens en natuur word beheer deur 'n morele respek en bewondering vir die natuur, die omgewing, die land. Vir Leopold is dit ondenkbaar dat 'n etiese verhouding tot die omgewing sonder liefde, respek en bewondering vir die land kan bestaan. Hierdie respek en bewondering is 'n noodsaaklike grondpilaar vir die uitbou van 'n ekologiese etiek. Sy land ethics verander die rol van homo sapiens vanaf veroweraar tot gewone lid van die landgemeenskap (Leopold, 1968:204). Die interafhanklikheid en simbiose van lede is die grond van morele relevansie.

'n Utilistiese riglyn bestempel alles wat nuttig en voordelig vir die mens is daarom ook as moreel goed. Daarteenoor kom Leopold met die gedagte dat as die gesondheid (= die vermoë tot interne selfvernuwing, integriteit en stabiliteit) van die biotiese gemeenskap bewaar word, dan is dit goed; word dit bedreig, is dit sleg - Leopold, 1968:224-225). Nie die nuttigheid van die land nie, maar die gesondheid van die land is die maatstaf vir ons morele optrede teenoor die land.

Civilization is not ... the enslavement of a stable and constant earth. It is a state of mutual and interdependent co-operation between human animals, other animals, plants and soils ... (Leopold, 1970:45).

In Wes-Europese lande het die sogenoemde 'Groenes' reeds die buitelyne van so 'n 'landetiek' en gepaardgaande landpolitiek uitgestippel. Die omgewing word sentraal gestel en baie waarde word aan omgewingsbewaring geheg deur alternatiewe vorme van woon, alternatiewe voedsel en -produksiemetodes, en deur alternatiewe ontspanningsgewoontes te propageer. In 'n leesboek oor 'n alternatiewe ekonomie word selfs van "ontmanteling van die groei-ekonomie" gepraat (Van den Abbeele, 1985:7). Die mens moet die ritme van haar lewensonderhoudende planeet 
in ag neem sodat uitbuiting plek mak vir simbiose (Roszak, 1980:82). Dit word liefs 'n kwessie van matter over mind; die belange van die natuur geniet voorkeur bo die belange van die mens. Skolimowski (1985) gaan selfs so ver as om te praat van die superioriteit van lewe en om te sê dat lewe gaan voor denke: filosofie het bestaansreg as dit die lewe versterk; filosofie is gelyk aan ekofilosofie (Skolimowski, 1985:39 e.v.; 119 e.v.). Ekofilosofie se respek vir die natuurlewe is gebaseer op "... een besef dat wij een verlengstuk van de natuur zijn en de natuur een verlengstuk van ons" (Skolimowski, 1985:48).

Die nadruk word gelê op 'n 'holistiese' benadering waarby alles as 'n deel van 'n groot geheel gesien word (Skolimowski, 1992:39-55). Teenoor die skerp skeiding en diskontinuïteit wat die antroposentriese omgewingsetiek tussen mens en omgewing handhaaf, word in die ekosentriese etiek 'n kontinuïteit of ' $n$ graduele gelykskakeling geproklameer. Maar daarmee het die natuursentriese etiek en ekofilosofie botsende belange tussen mens en natuur probeer oplos deur die mens se belange te herlei na dié van die natuur. Versoening tussen die belange van die mens en die belange van die natuur vind plaas deur ' $n$ onderskikking van denke en kultuur aan lewe en natuur, deur 'n reduksie van die mens na die biotiese gemeenskap. Ook Achterberg (1986) wys op die spanning in Leopold se 'landetiek' waar hy land enersyds as biotiese gemeenskap beskryf en andersyds die gemeenskap as moreel relevant beskou vanweë 'n biotiese afhanklikheid van sy lede (Achterberg, 1986:11; 13-14). Die biotiese en die morele is nie sonder meer met mekaar te rym nie (= kan nie sonder meer in terme van mekaar verklaar word nie). Uiteraard het ons waardering vir die gedagte dat mens en natuur innerlik verweef is en wedersyds afhanklik is, maar dat natuurdinge 'n eie onherleibare waarde het, spreek ons ook sterk aan. Innerlike verweefdheid verhoed egter nie dat elk van genoemde pole 'n eiestandigheid openbaar wat nie tot mekaar herleibaar is nie. Daarsonder sou simbiose byvoorbeeld ondenkbaar wees.

Versoening tussen 'land' en 'etiek' behoort dus in 'n ander rigting (as reduksie van die een na die ander) gesoek te word. Watter rigting ons moet soek, kan aangevoor word met die vraag: hoe kan versoening bereik word met behoud van die eie waarde van elk? Die kernvraag is hoe om natuur en mens, milieu en sosiale gemeenskap, lewe en moraliteit ooreenkomstig hul eie aard maar in belang van albei te ontplooi. In die gees van Schweitzer kan 'n mens vra: hoe kan diere en ander natuurdinge in ons etiek vreedsaam saam met die mens rondloop en floreer? 


\section{4. 'n Omgewingsetiek ten gunste van mens én natuur?}

Die afgelope twee dekades soek skrywers ook na 'n versoening tussen die antroposentriese en die milieusentriese benadering. Die Amerikaner Ian Barbour was met sy interdissiplinêre benadering die voorloper van so 'n sintese (vgl. Barbour, 1980). Die Brit Attfield en die Nederlandse kollegas Achterberg en Zweers en die Vlaamse akademikus Vermeersch het as inisiatiefnemers op filosofiese gebied bekend geraak (vgl. onder andere Vermeersch, 1993).

Zweers (1986) sien omgewingsetiek as 'n ondersoek na die aard en grond van daardie norme waardeur die mens hom laat lei in sy optrede teenoor natuur en milieu. Zweers (1986) wil meewerk aan 'n nuwe milieu-etiek ter vervanging van 'n etiek waarby slegs menslike belange tel. Hy het ook reserwes oor 'n nie-antroposentriese milieu-etiek wat ekosentries in die natuur as norm gefundeer word (Achterberg \& Zweers, 1986:21.). Hy vrees tereg dat as ons die antroposentriese omgewingsetiek (met die mens as norm) gaan inruil vir 'n milieusentriese etiek (gebaseer op die natuur as norm), dan kan dit sosiaal-filosofies lei to 'n heillose teenstelling tussen milieuwaardes en sosiale waardes (Achterberg \& Zweers, 1986:22).

In die gees hiervan wil Achterberg milieu-etiek ook 'n sosiale etiek noem (vgl. Achterberg, 1986:79). So 'n sosiale omgewingsetiek beoog om morele prinsipes en reëls op te stel wat toegepas kan word in kollektiewe beslissings oor natuurbeskerming, natuurherstel en natuurbeheer. Die morele prinsipes is gebaseer op die morele respek vir die natuur self (Achterberg \& Zweers, 1986:160-166). Vir hom het die natuur nie slegs ' $n$ instumentele waarde wat (antroposentries) deur die mens toegeken is nie; die natuur het 'n eie objektiewe intrinsieke waarde wat veral verband hou met die idee van selfordening van die natuur (Achterberg \& Zweers, 1986:29).

Om 'n nuttigheidsperspektief op ons omgewing te hê is nie noodwendig egoïsties en boos nie. Wanneer dit egter die enigste en allesoorheersende perspektief word, versper dit 'n verstaan van die oerkwaliteite van ons wêreld en van die mens. So vervreem ons onsself van die natuur wat slegs as piekniekplekke of as eiendomsontwikkeling of as kleim vir mineraalontginning herken kan word. Dan word die misterie en die meervoudigheid van bestaan misgekyk.

'n Omgewingsetiek wat die milieu/omgewing/natuur sentraal stel, benader die verhouding tussen mens en natuur/omgewing/milieu meestal vanuit 'n 
P.G.W. du Plessis

biologisme wat net op die biologiese verwantskap en vitale verweefdheid fikseer. Dit is ook ' $n$ vitalistiese beskouing wat oorlewing self tot norm van die verhouding verhef. Oorlewing is myns insiens egter self geen norm van lewe (van natuurlewe of menslike lewe) nie; ons moet oorlewing aan norme toets om vas te stel of dit wel mens- en natuurvriendelike oorlewing is waarmee ons besig is; met ander woorde of dit 'n oorlewing is wat die uniekheid asook die vervlegting van natuur en mens eerbiedig. Die norme (vir oorlewing) kan nie langer die reëls vir the good life in die ou betekenis van 'n egosentriese en mensgesentreerde goeie lewe wees nie (Barbour, 1980:304-319).

Die mens is nie die bron van alle waarde nie; daarom sal ons die goeie lewe moet herdefinieer om nie meer status, begeerte, mag, hebsug, winsbejag, gulsigheid, gemaksugtigheid of blote welvaart en weelde ten koste van die natuur en omgewing te beteken nie. 'n Nuwe lewenstyl met norme gekoppel aan beskeidenheid, matigheid, selfdissipline, naastediens en sorg vir die omgewing is nodig. Ons het 'n behoefte aan 'n nuwe reklame- en besigheidsetiek wat die nywerheid en sakewêreld se strewe om die mens se manie en swakheid vir luukshede, vir foefies, vir mag en vir status uit te buit, te ontmasker (Du Plessis, 1988:262).

Of is die oplossing vir bovermelde probleme miskien daarin geleë dat verdere tegnologiese kundigheid aangewend moet word om die skaarste aan grondstowwe op te los en die besoedeling van die natuur teen te werk? Nee.

Bestrijden van pollutie is mogelijk, maar meestal met behulp van supplementaire apparatuur, wat dan weer verhoogde productie, grondstoffen- en energieverbruik veronderstelt; kortom, de ontwikkeling van het WTK-bestel [= wetenskaplike, tegnologiese en kapitalistiese bestel - PGW du P.] verder aanzwengelt (Vermeersch, 1993:48).

Tereg word dié suggestie die "fallacy of unfinished business" genoem (Achterberg \& Zweers, 1986:8). Hierdie suggestie veronderstel dat egte antwoorde op besoedeling nog meer tegnologie en groei is. Verder sou so 'n uitgangspunt impliseer dat tegnologie en ekonomiese groei geen skadukante het nie en in staat is om as selfverlossende magte op te tree. Intussen weet en ervaar hedendaagse burgers van veral ons Westerse wêreld dat ons tegnologiese en industriële vooruitgang deurlopend nuwe skaarstes laat ontstaan het - 'n skaarste wat nie gekenmerk word deur besoedeling of onessensiële foefies nie. Goudzwaard noem hierdie skaarste in sy publikasie van 1970 "ongeprijsde schaarste". Hierdie ongeprysde 
Omgewingsetiek ten gunste van natuur én mens?

skaarste is 'n skaarste aan skoon lug en water, aan onverminkte ekosisteme, aan voldoende natuurlike hulpbronne en 'n skaarste aan natuurlike en menslike stilte.

Daarom sal ons in ons nuwe etos moet breek met 'n moderne oorskatting van en 'n kritieklose geloof aan tegnologie en ekonomiese groei as gelukbringers op alle terreine. Wetenskap en tegniek en geld kan wel bydraes lewer tot welvaart, maar hulle is geen voldoende waarborge vir die welsyn van omgewing en samelewing nie. Indien die outoriteit van wetenskap, tegniek en ekonomie nie bevraagteken mag word nie, het ons 'n nuwe probleem vir die mens en sy omgewing geskep: dié van die tegnokratiese en ekonomiese diktatuur. Die oplossing van besoedelings- en omgewingsprobleme is nie slegs 'n kwessie van geld, tegnies-wetenskaplike kundigheid, mannekrag en tyd nie; dit is eerder 'n kwessie van 'n nuwe lewenstyl wat deur indiwidu, gemeenskap, owerheid en belange-instansies aangedurf moet word.

'n Nuwe omgewingsetiek sal vorentoe moet meewerk aan interdissiplinêre studies van die non-instrumentele waarde wat stof, plant en dier in ons omgewing het. Die enigste waardes op aarde is tog nie die mensgesentreerde waardes nie. Daarom sal ons omgewingsetiek van die toekoms 'n etiek moet wees wat verby egoïsme, hedonisme en utilisme beweeg en wat 'n eensydige mensgesentreerde benadering afsweer (Barbour, 1980:8). Tot dusver het die mens maar al te graag natuurdinge slegs as gebruiksgoedere raakgesien. Ons verbruikerskultuur sit ons oogklappe aan sodat ons nie meer die omgewing in sy eie reg en waarde opmerk en waardeer nie. Daarmee word ons natuurblind en is ons bly as plastiekblomme 'dieselfde funksie' (sic!) kan verrig as natuurblomme. "To the Christian mind all the non-human creatures have an intrinsic value. It is wrong to handle non-human living things and the land as nothing but chattels and property" (Du Plessis, 1988:262).

\subsection{Christendom en natuuromgewing}

Ondanks bovermelde erkenning van die eie waarde van natuurdinge word die hedendaagse omgewingskrisis soms voor die deur gelê van die Christendom met sy opdrag aan die mens om oor die aarde, die diere, die voëls, die plante te heers. Lynn White jnr. praat van die tipiese 'Christelike arrogansie' teenoor die natuur. In teenstelling met die natuurgodsdienste se vergoddeliking van die natuur, bevat die aarde vir die Christendom geen goddelike kragte nie. Die mens is egter wel heilig, omdat hy na 
P.G.W. du Plessis

die beeld van God gemaak is. In die skepping staan die mens dus sentraal (White, 1970:18-26). Die Christendom is volgens White en talle ander daarom 'n sterk aandeelhouer in die antroposentriese benadering en uitbuitersmentaliteit teenoor die omgewing (onder andere Breuilly \& Palmer, 1992:7 e.v.).

Verskeie skrywers toon egter aan dat die Stoa en die Renaissance en die Puriteine ' $n$ beduidende invloed op die Christendom uitgeoefen het met die antroposentriese gedagte dat die mens die einddoel en bobaas van die natuur sou wees. Ook is dit eerder 'n Pelagiaanse gedagte wat die mens oproep om in die natuur in te gryp en dit met tegniese middels te veredel (vgl. onder andere Passmore, 1974; Schuurman, 1985; Breuilly \& Palmer, 1992; Vermeersch, 1993). Vir sover die Christendom die gees van eksploitasie bevorder het, moet volgens Schuurman van 'n gesekulariseerde Christendom gepraat word.

Meer dan een christen heeft sich door het technicisme laten beinvloeden. Hij is sich als 'heer en meester' van de natuur gaan gedragen en heeft daarbij de eigen waarde en zin van de natuurzijde van de schepping meer en meer uit het oog verloren (Schuurman, 1985:34).

Ian Barbour se verweer teen die beskuldiging wys daarop dat die negatiewe dominion-idee en -praktyk nie tiperend van die Bybelse opdrag aan die mensheid is nie. Hy skryf:

Note that:

1. Several nonbiblical sources of the dominion theme can be identified in the West;

2. The stewardship theme in the Bible itself sets limits on dominion, which were subsequently ignored;

3. Environmental destruction has been common in nonbiblical cultures of both East and West since antiquity; and

4. Institutions as well as ideas must be examined as determinants of environmental behavior, even if institutions are themselves partly the product of ideas (Barbour, 1978:367).

Wilkinson (1981) onderskei tussen Christianity ( $=$ Bybelse leer oor skepping en verlossing) en Christendom, en gee toe dat die Christendom (= Christene in hulle daaglikse lewe en werk) hom wel skandelik skuldig gemaak het aan allerlei uitbuiting en besoedeling en verwaarlosing van die milieu:

Christians have interpreted the biblical teaching on human dominion over nature - and divine transcendence over the world - as a licence for the ruthlessly exploitative subjugation of nature. But, ... the most important excep-

Koers 60(2) 1995:325-346 
Omgewingsetiek ten gunste van natuur én mens?

tion to our agreement with those accusations of White - or MacHarg - is that this ruthlessness results from Christians misunderstanding and misusing Scripture, rather than the actual teaching of Scripture itself (Wilkinson, 1981:204).

Ook Palmer (1992:88-94) erken dat die eerste hoofstukke van Genesis vir baie Christene gedien het as 'n manifes vir ons human use of nature. Veral die Puriteinse Calviniste het met geringskatting van die fisiese natuur gepraat en gehandel. Palmer wys egter daarop dat daar ook talle ander Protestantse en Roomse Christene was wat die kultuuropdrag aan die mens anders en Bybels verstaan het: om te heers beteken die regte gebruik van en rentmeesterskap oor die natuur (Breuilly \& Palmer, 1992:88-94).

Die mens se heerskappy oor die aarde word reeds in die Ou Testament duidelik gekwalifiseer deur sy verantwoordelikheid vir die skepping teenoor die Skepper. Die aarde en sy volheid behoort aan die Here en die mens moet as kurator, hofmeester, versorger, rentmeester, kultiveerder daarvan optree. Die mens se belangstelling in en bemoeienis met die natuur en sy omgewing word genormeer en gerelativeer deur sy verantwoordelikheid en rentmeesterskap. Die mens is verantwoordelik vir sy sorg vir die aarde en vir die voortdurende ontwikkeling daarvan. Heerskappy oor stof, plant en dier (en medemens) beteken nie dat die mens sy natuur- en kultuuromgewing in eie belang mag manipuleer nie. Die mens is ' $n$ rentmeester, 'n bewaarder, 'n versorger van die aarde - nie die eienaar of baas daarvan nie.

Wanneer we de eisen van rentmeester-zijn serieus nemen, vergt dat een vooropstellen van normen van menswaardigheid in de arbeid. .... Het vergt ook de handhaving van strikte grenzen voor het beschadigen van de natuur (Goudzwaard, 1981:106)

Ian Barbour formuleer die idee van die mens se verantwoordelikheid teenoor die natuur as 'n alternatief op die antroposentriese omgewingsetiek van oorheersing en noem dit 'n omgewingsetiek van rentmeesterskap: "'Stewardship' implies the co-operation and partnership of man and nature for the fulfilment of the highest potentialities of both" (Barbour, 1978:365).

Genoemde negatiewe koppeling tussen Christendom en die mens se heerskappy het 'n sekere parallel met die bekende opvatting van Max Weber oor die skakel tussen Christendom en kapitalisme. Goudzwaard gee toe dat "... historically speaking there is definitely a connection between capitalism and Calvinism through the intermediary of later Purita- 
nism" (Goudzwaard, 1979:8) maar stel dat dit histories en prinsipieel moeilik is om 'n regstreekse skakel tussen Bybelse Christendom en kapitalisme met sy aggressiewe vooruitgangsmotief te vind. $\mathrm{Al}$ is daar 'n diskrepansie tussen die de jure-opdrag aan die Christenmens en die de facto-skrikverhaal van sy optredes, bly die kwalifikasie van die mens as rentmeester, as versorger 'n deurslaggewende norm vir sy hantering van die natuur/omgewing/milieu.

Die Bybelse demitologisering van die natuurwêreld akkommodeer juis nie die outonomieverklaring van die mens en sy rede soos uitgewerk deur die Renaissance asook die Verligting en 'n rasionalisme nie. Die Calvinistiese Christendom lê groot klem op die kreatuurlike afhanklikheid van die mens. Daarom moet hy as verantwoordelike rentmeester voor Gods aangesig alleen uit genade - en nie uit verdienste nie - werk, ontspan en versorg. Mens en natuur is op mekaar aangewys. Selfs die skeppingsverhaal toon dat die aarde belangrik was (en is) vir die menswording van Adam (en vir ons eie humaniteit). Die natuurdinge in ons omgewing is ons medekreature wat ons menslikheid na vore kan bring.

\section{2 'n Nuwe etos}

Die inherente waarde van natuurdinge is tog veel meer as net ekonomiese waarde. Die eie waarde loop hand aan hand met die eiestandigheid van die entiteit: dit wat die entiteit tot homself maak. Ons respek en sorg vir natuurdinge word ontleen aan die eie status van natuurdinge. Die inherente waarde en morele status van natuurdinge word deur mense ervaar en vasgestel. Die verskil tussen die morele status van natuurdinge en die morele status van mense word soms uitgedruk in terme soos moral patient en moral agent. Die status van morele agent word toegeken aan mense wat subjekte is van regte en pligte en wat ons moreel verantwoordelik kan hou vir hulle dade.

De status van 'moral patient' kennen we toe aan wesens die niet zelf morele verantwoordelijkheid kunnen dragen maar van wie de belangen toch moreel gewicht hebben, op morele gronden gerespecteerd dienen te worden (Achterberg, 1986:55).

'n Mens kan ook praat van natuurdinge as morele objekte en van die mens as 'n morele subjek. Dit beteken dat natuurdinge deur die mens as morele objekte in eie reg behandel kan word, omdat natuurdinge in hulleself die vermoë en eienskappe daartoe het. Ook die natuurdinge roep om geken en versorg te word. Natuurdinge ontleen nie hul waardekarakter aan die 
mens nie. Wanneer die mens 'n antwoord probeer gee op die behoefte en uitnodiging van die nie-menslike wêreld om geken en versorg te word, ontstaan 'n nuwe etos. So kan ons 'n omgewingsetiek ontwikkel wat die eie-waarde, die ontologiese vraag van die natuur as iets objektiefs erken. Die natuur ontleen nie sy eie-waarde aan die mens nie. Natuurdinge het ook eie intrinsieke waardes wat die mens as voorafgegewenes of antesendente of geskenke in sy persepsies en optredes teenoor die natuur kan ontdek en hanteer.

Ons deel ' $n$ biologiese bestaanswyse met die baie lewende wesens in die natuur. Hierin het woordvoerders van 'n vitalistiese milieusentriese etiek gelyk. Naas die biotiese natuuromgewing beteken 'milieu' egter tog ook stof, energie en lig. Verder kan 'milieu' ook die anorganiese, die organiese en die kulturele of sogenaamde geestelike werklikheid behels. Dit kan die kultuuromgewing wees waarin ons grootword, werk, leer praat, sosiaal verkeer, ontspan; waarin ons regpleeg, bid, wetenskap bedink, handel dryf en kuns beoefen. Ja, ons deel 'n organiese wêreld met plant en dier, maar ons deel veel meer met alle natuurdinge.

Ons deel ook ' $n$ morele bestaanswyse met alle natuurdinge: organies of anorganies - al is natuurdinge moreel passief of slegs morele objekte en nie morele agente of morele subjekte soos die mens nie. Al bly dit 'n lastige (kenteoretiese) vraag hoe ons die inherente morele waarde van natuurdinge kan ken, ervaar en weet die huidige generasie: natuurdinge hét 'n meer-waarde as nuttigheidswaarde. Natuurdinge hét 'n eiewaarde wat nie deur die mens gemaak is nie, maar wat deur die mens gedeeltelik ontplooi kan word. Ten opsigte van dié aspek is sprake van antesedente of voorafgegewenes in die natuur buite ons toedoen om. Die ervaring en erkenning dat natuurdinge ' $n$ eie morele status het, is ook fundamenteel vir die uitwerk van 'n omgewingsetiek van verantwoordelike rentmeesterskap.

lets van die eiestandigheid van natuurdinge kom ook na vore in die verhaal van Job. God gee aandag aan die natuur, selfs buite die mens om. Die ondervraging van Job maak ons nederig by die besef: wat weet die mens tog van die geheim tussen God en die natuur? Miskien moet ons weer soos Job herinner word aan die voortyd toe daar slegs diere - en geen mens - op aarde was. Toe het God hom verheug oor die goedheid van die skepping se bome, plante, sterre, see en diere lank voor die verskyning van die mens op aarde. Ons kennis en kunde oor die eieheid van natuurdinge het opvallende grense. 
Die etiek van rentmeesterskap baseer die mens se verantwoordelikheid teenoor sy/haar omgewing op verskille met sowel as op die verbondenheid met die natuuromgewing (Du Plessis, 1988:258 e.v.). Daar is talle verskille tussen mens en natuur. Daar is soveel verskille dat die een nie in terme van die ander verklaarbaar is nie. Sonder om in 'n debat oor die verskil(le) tussen mens en natuur te versand, kan ons daarop wys dat die mens ' $n$ ongeneeslike kultuurwese is wat sy/haar leefwyse fundamenteel kan verander (byvoorbeeld vanaf jag na organisational person) sonder om genetiese veranderings te ondergaan. In die natuur is die verandering van lewenswyse of van ekologiese nis alleen moontlik deur 'n proses van soortvorming (Achterberg, 1986:72-73).

$\mathrm{Al}$ is die mens uniek in die skepping (bv. die gawe en opgawe om beeld van God te wees of sy/haar rol as rentmeester/herder van die natuur), is hy/sy maar een van talle skepsels en verweef met die aarde en alles daarop en daarin. Wat die ganse skepping byeenhou, is 'n netwerk verskille en samehange. Die samehang en die verbondenheid tussen mens en natuur beteken onder andere dat ons op analoë wyse dieselfde morele gedrag teenoor natuurdinge verskuldig is. Waar die mens byvoorbeeld 'n lewende wese soos alle ander lewende wesens is, het hy ook die roeping om die belange van daardie natuurdinge so te behandel dat hulle tot groter ontplooiing van hulleself kan kom.

Maar ook die grense van wetenskap en tegniek word vandag toegegee. Wetenskap en tegniek moet van hulle sentrale plek teruggedring word. Wetenskap en tegniek mag nie 'n oorheersende plek in die natuur of kultuur inneem nie; dit moet 'n dienende rol speel.

\begin{abstract}
In plaas van die oorheersende motief van mag, gee die sentrale motief van liefde 'n ryke verskeidenheid aan die verskillende kultuuraktiwiteite. Dit beteken dat dit in die wetenskap om groei in wysheid sal gaan; in die tegniek om bou en bewaar; in die landbou om oes, beskerm en versorg; in die ekonomie om rentmeesterskap en in die politiek om die dien en bevorder van reg en openhare geregtigheid. Hiermee is die verskillende gekwalifiseerde verantwoordelikhede van die mens en hulle onderlinge onherleibaarheid gewaarborg. Hierdie verskeidenheid is die regte weg om tot 'n sinvolle ontsluiting (in die sin van ont-wikkeling) van ons kultuuraktiwiteite te kom (Schuurman, 1988:17).
\end{abstract}

Die mens het ' $n$ groot verantwoordelikheid in die najaag van vrede, in die deurgee van welsyn aan sy naaste en in die ontplooiing van die eiewaarde van die natuur - al is vrede, welsyn en bestemmingsontplooiing nie menslik produseerbare items nie; dit is geskenke wat ons met vaste hoop moet 
Omgewingsetiek ten gunste van natuur én mens?

waarmaak. Om te leef uit 'n Messiaanse hoop, impliseer nie passiwiteit nie, maar juis aktiwiteit: oral moet die Christengelowige ook tekens van Gods genade en redding oprig. Ons is nie slegs vennote (medewerkers) van die Skepper in die natuur nie, ons is ook vennote van die (Skepper se) natuur. Daarom kan ons etiek meer in die oorspronklike betekenis van etos gebruik: morele leefwyse en gewoontes. Ons omgewingsetiek is 'n pleidooi vir 'n nuwe etos, dit wil sê 'n nuwe morele leefwyse waarin respek vir die eie waarde van die omgewing en natuurdinge ons dring om op verantwoordelike wyse die nodige sorg (onder andere ontbesoedeling) en ontplooiing daarvan aan te pak. In 'n sekere opsig kan ons Vermeersch (1993:65) ondersteun as hy sê: “... de stap van inzicht naar daadwerkelijke hervormingen, moet worden gedragen door een morele instelling die we eco-ethiek noemen. ... Hieruit moet een algemene habitus ontstaan van respect voor alles wat vorm en gestalte heeft gekregen ...".

Grense en die beperktheid van ondermaanse dinge vorm juis 'n aanloop vir die beantwoording van die vraag na die sin en waarde van ons natuuromgewing en van die mens en sy samelewing. As daar gereelde aandag bestee word aan die kwesbaarheid van die milieu, die beperktheid van natuurlike hulpbronne, die tekort aan finansiële middele, die interafhanklikheid tussen omgewing en mens en les bes - ook aan die grense van wetenskaplik-tegniese manipulasie van natuur en mens - dan dring dit ons om na 'n nuwe etos met nuwe prioriteite te soek: om nuwe lewenswaardes, nuwe lewenstyle, nuwe verhoudings teenoor die omgewing tot stand te bring.

Vir 'n nuwe omgewingsetiek beteken 'die goeie lewe' 'n soeke na 'n dinamiese balans en na 'n kreatiewe interaksie tussen mens en omgewing (Barbour, 1980:29; 306-316). Juis deur sy verskil met die res van die skepping (waar onder sy reflekterende selfbewussyn, sy toekomsgerigte beplanning, sy kreatiwiteit en sy rentmeesterskap) kan die mens in interaksie met sy omgewing tree. Die redding van die natuur en die mens lê nie daarin dat die mens opgaan in die natuurprosesse nie. Die antwoord op 'n antroposentriese etiek se slagspreuk mind over matter is nie 'n omgekeerde slagspreuk matter over mind van die natuursentriese etiek nie.

Mens en natuurdinge het ' $\mathrm{n}$ relatiewe selfstandigheid, ' $\mathrm{n}$ eieheid wat in relasie tot mekaar na vore kom. Sonder die natuur en sy diere kan omgewingsetiek nie tot stand kom nie Die mens word eties, ook via die natuur. Die mens is geen geïsoleerde etiese wese nie; hy is geen 'ek dink, dus ek bestaan' nie. Nee, ons (= natuur en mens) bestaan: dus ek dink oor 
P.G.W. du Plessis

ons natuuromgewing verantwoordelik of slordig; dus ek ontplooi of eksploiteer die natuur; dus ek behandel die natuur moreel of immoreel. Ons etiese bestaan kom tot stand in ons verhoudings (met medemense en) met die natuur.

Omgewingsetiek gaan in die nabye toekoms eerder ontstaan in die beperkte stoeiruimte en eindige simbiose tussen mens en natuur. Waar mens en natuur soms koppe stamp en soms hande vat, daar moet hy ook 'n herdersetos teenoor die natuur vestig. Hopelik sal filosowe en ander denkers binne Christelike kring in die nabye toekoms met genoemde nuwe etos en sy anderse prioriteite 'n eie bydrae tot omgewingsetiek kan lewer.

\section{Literatuur}

ACHTERBERG, W. 1986. Partners in de natuur. Amsterdam : Jan van Arkel. ACHTERBERG, W. \& ZWEERS, W. 1986. Milieucrisis en filosofie. Amsterdam : Ekologische Uitgeverij.

ATTFIELD, R. 1983. The Ethics of Environmental Concern. Oxford : Blackwell.

BARBOUR, I.G. 1978. Environment and Man. (In Encyclopedia of Bioethics. New York: Free Press N.Y. p. 366-373.)

BARBOUR, I.G. 1980. Technology, Environment and Human Values. New York : Praeger.

BREUILLY, E. \& PALMER, M. 1992. Christianity and Ecology. London : Cassell.

CARSON, R. 1962. Silent Spring. New York : Penguin.

DU PLESSIS, P.G.W. 1988. Environmental Ethics of the Future. Koers, 53(2):253-265.

GOUDZWAARD, B. 1970. Ongeprijsde schaarste. Den Haag : Van Stockum.

GOUDZWAARD, B. 1979. Capitalism and Progress. Grand Rapids : Eerdmans.

GOUDZWAARD, B. 1981. Genoodzaak goed te wesen. Kampen : Kok.

LEOPOLD, A. 1968. The Land Ethic. (In Leopold, A. A Sand County Almanac. Oxford : Oxford University Press. p. 201-226.)

LEOPOLD, A. 1970. The Conservation Ethic. (In Disch, R. ed. The Ecological Conscience: Values for Survival. New York : Englewood Cliffs. p. 44-55.)

MACHOVEC, M. 1988. Die Rückkehr zur Weisheit. Stuttgart : Kreuz Verlag.

MERCHANT, C. 1985. The Death of Nature. San Francisco : Harper and Row.

MESAROVIC, M. \& PESTEL, E. 1974. Mankind at the Turning Point. New York : Dutton. 
PASSMORE, J. 1974. Man's Responsibility for Nature. London : Duckworth. REICH, C. 1972. The Greening of America. Harmondsworth : Penguin.

ROSZAK, Th. 1968. Making of a Counter Culture. New York : Faber.

ROSZAK, Th. 1980. Persoon en planeet. Amsterdam : Meulenhoff.

SCHUMACHER, E.F. 1978. Small is Beautiful. New York : Harper.

SCHUURMAN, E. 1985. Tussen technische overmacht en menselijke onmacht. Kampen : Kok.

SCHUURMAN, E. 1988. Krisis in die landbou. 'n Reformatories-wysgerige perspektief. Potchefstroom : IRS. (IRS-studiestuk no. 249.)

SKOLIMOWSKI, H. 1985. Ecofilosofie. Nijmegen : Markant.

SKOLIMOWSKI, H. 1992. Living Philosophy. Eco-philosophy as a Tree of Life. London : Arkana/Penguin.

STOKER, H.G. 1967. Oorsprong en rigting. Deel 1. Kaapstad : Tafelberg.

VAN DEN ABBEELE, E. (e.a.). 1985. Ontmanteling van de groei. Nijmegen : Markant.

VERMEERSCH, E. 1993. De ogen van de panda; een milieufilosofisch essay. Brugge : Marc van de Wiele.

WHITE, L. 1970. The Historical Roots of Our Ecological Crisis. (In De Bell, G. ed. The Environmental Handbook. New York : Ballantine. p. 12-26.)

WILKINSON, L. ed. 1981. Earth Keeping. Christian Stewardship of Natural Resources. Grand Rapids : Eerdmans.

ZIJDERVELD, A.C. 1985. Vernieuwing als mythe. (In Von der Dunk, H.W. e.a. De paradoxen van de vernieuwing. Nijmegen : Markant. p. 41-50.) 